\title{
PENGARUH MODEL EXPLICIT INSTRUCTION TERHADAP HASIL BELAJAR BAHASA INDONESIA MEMBACA KONSEP DENAH PADA MURID KELAS IV SD
}

\author{
Nurvitriawati, Sulfasyah \\ Pendidikan Guru Sekolah Dasar, Fakultas Keguruan dan Ilmu Pendidikan \\ Universitas Muhammadiyah Makassar \\ Nurvitriawatipgsd@gmail.com
}

\begin{abstract}
ABSTRAK
Penelitian ini bertujuan untuk mengetahui Pengaruh Model Explicit Instruction terhadap Hasil Membaca Bahasa Indoensia Konsep Denah pada Murid Kelas IV SD Inpres Bertingkat Kecamatan Somba Opu Kabupaten Gowa. Jenis Penelitian ini adalah penelitian pra eksperimen yang hanya melibatkan satu kelas dan dilaksanakan sebanyak dua kali pertemuan. Satuan eksperimen di lakukan secara acak (random). Jenis penelitian ini adalah penelitian Eksperimen one group pretest-posttest desaign. Sampel dalam penelitian ini adalah siswa kelas IV SD Inpres Bertingkat Kecamatan Somba Opu Kabupaten Gowa sebanyak 23 orang. Adapun instrument yang digunakan berupa tes hasil belajar dan lembar observasi siswa dan dokumentasi. Hasil penelitian ini menunjukkan bahwa penggunaan Model Explicit Instruction dalam pembelajaran Bahasa Indonesia dengan materi Konsep Denah berpengaruh terhadap hasil membaca siswa kelas IV SD Inpres Bertingkat Kecamatan Somba Opu Kabupaten Gowa. Keadaan ini dapat dilihat dari hasil tes yang menunjukkan bahwa posttest yang diberi perlakuan melalui Model Explicit Instruction mendapatkan nilai rata-rata lebih tinggi yaitu 69,47 dibandingkan dengan pretest yang tidak menerima perlakuan melalui model Explicit Instruction yaitu 47,65. Berdasarkan uji $t$ baik taraf signifikan $5 \%$ diperoleh $t_{\text {hitung }} 7,45$ dan $t_{\text {tabel }} 1,71$, karena $t_{\text {hitung }}>t_{\text {tabel }}$ maka ada pengaruh dalam penerapan Model Explicit Instruction terhadap hasil membaca yang diberi perlakuan melalui model Explicit Instruction. Maka berdasarkan pengujian tersebut penggunaan Model Explicit Instruction berpengaruh jika diterapkan pada proses pembelajaran Bahasa Indonesia dengan materi konsep denah pada kelas IV SD Inpres Bertingkat Kecamatan Somba Opu Kabupaten Gowa.
\end{abstract}

Kata Kunci: Model Explicit Instructio; Hasil Belajar Siswa 


\section{PENDAHULUAN}

Meningkatkan mutu pendidikan adalah menjadi tanggung jawab semua pihak yang terlibat dalam pendidikan terutama bagi guru SD yang merupakan ujung tombak dalam pendidikan dasar. Guru SD adalah orang yang paling berperan dalam menciptakan sumber daya manusia yang berkualitas yang dapat bersaing di zaman pesatnya perkembangan teknologi. Jadi, singkatnya masalah yang dihadapi dalam dunia pendidikan adalah masalah lemahnya proses pembelajaran. Dalam proses pembelajaran siswa kurang didorong untuk mengembangkan keterampilan berpikir.

Dengan demikian, aktivitas pembelajaran benar-benar merupakan kegiatan bertujuan yang tertata secara sistematis. hal ini sejalan dengan apa yang dikemukakan oleh eggen dan kauchak bahwa model pembelajaran memberikan kerangka dan arah bagi guru untuk mengajar.

Ini merupakan tantangan yang diberikan kepada guru untuk bisa membuat peserta didik menyenangi mata pelajaran yang membahas aspekaspek kebahasaan tersebut. Ada pepatah yang mengatakan "kudengar aku lupa, kulihat aku ingat dan kulakukan aku bisa" maka dari itu penggunaan Model pembelajaran sangat penting untuk pembelajaran bahasa indonesia di sekolah.

Berdasarkan observasi awal yang dilakukan di SD Inpres Bertingkat pada tanggal 20 Desember 2016 diperoleh data bahwa guru dalam proses pembelajaran kurang mengefektifkan model sehingga ditemukan bahwa kemampuan dalam memahami pelajaran konsep denah oleh sebagian siswa masih tergolong rendah. Hal ini dibuktikan oleh data hasil ulangan harian.

Untuk itu peneliti memberiikan alternatif pemecahan masalah tersebut dengan menerapkan Model pembelajaran Explicit Instruction terhadap hasil belajar konsep denah kelas IV SD Inpres Bertingkat Kecamatan Somba Opu Kabupaten Gowa. Model Explicit Instruction di depinisikan salah satu pendekatan mengajar yang dirancang khusus untuk menunjang proses bealajar siswa yang berkaitan dengan penegetahuan deklaratif dan pengetahuna prosedural yang terstruktur dengan baik yang diajar dengan pola kegiatan bertahap, selangkah demi selangkah (Arends, 2001:264). Model pembelajaran Explicit Instruction yang dilengkapi dengan media kongkret yang ada disekitar 
kehidupan anak akan dapat membantu siswa dalam membangun pengetahuannya sendiri terutama dalam pembelajaran bahasa indonesia.

Berdasarkan uraian di atas rumusan masalah dalam penelitian ini adalah: :Apakah Penggunaan Model Explicit Instruction dapat Meningkatkan Hasil Membaca Bahasa Indonesia Konsep Denah Kelas IV SD Inpres Bertingkat Kecamatan Somba Opu Kabupaten Gowa?". Tujuan penelitian ini adalah untuk mengetahui Pengaruh Model Explicit Instruction terhadap Hasil Membaca Bahasa Indonesi Konsep Denah Kelas IV SD Inpres Bertingkat Kecamatan Somba Opu Kabupaten Gowa.

\section{Hasil Belajar}

Menurut Nawawi (Susanto, 2016:5) yang menyatakan bahwa hasil belajar dapat diartikan sebagai tingkat keberhasilan siswa dalam mempelajari materi pelajaran di sekolah yang dinyatakan dalam skor yang diperoleh dari hasil tes mengenal sejumlah materi pelajaran tertentu.

Secara sederhana, yang dimaksud dengan hasil belajar siswa adalah kemampuan yang diperoleh anak setelah melalui kegiatan belajar. Karena belajar itu sendiri merupakan suatu proses dari seseorang yang berusaha untuk memperoleh suatu bentuk perubahan perilaku yang relatif menetap.

Untuk mengetahui apakah hasil belajar yang dicapai telah sesuai dengan tujuan yang dikehendaki dapat diketahui melalui evaluasi. Sebagaimana dikemukakan oleh Sunal (Susanto, 2016:5) bahwa evaluasi merupakan proses penggunaan informasi untuk membuat pertimbangan seberapa efektif suatu program telah memenuhi kebutuhan siswa. Selain itu, dengan dilakukannya evaluasi atau penilaian ini dapat di jadikan feedback atau tindak lanjut, atau bahkan cara untuk mengukur tingkat penguasaan siswa. Kemajuan prestasi belajar siswa tidak saja diukur dari tingkat penguasaan ilmu pengetahuan, tetapi juga sikap dan keterampilan. Dengan demikian, penilaian hasil belajar siswa mencakup segala hal yang dipelajari di sekolah, baik itu menyangkut pengetahuan, sikap, dan keterampilan yang berkaitan dengan mata pelajaran yang diberikan kepada siswa.

Selanjutnya, dikemukakan oleh Wasliman (Susanto, 2016:13) bahwa sekolah merupakan salah satu faktor yang ikut menentukan hasil belajar siswa. Semakin tinggi kemampuan belajar siswa dan kualitas pengajaran 
di sekolah, maka semakin tinggi pula hasil belajar siswa.

\section{Keterampilan Membaca}

Henry Guntur Tarigan (2008:7) mengungkapkan bahwa membaca adalah suatu proses yang dilakukan untuk memperoleh pesan, yang hendak disampaikan oleh penulis melalui media kata-kata/bahasa tulis. Hal senada juga dikemukakan oleh Harjasujana (melalui Khuddaru Sadhono, 2012:65) yang menyatakan bahwa membaca merupakan kegiatan merespon lambang-lambang tertulis dengan menggunakan pengertian yang tepat.

Dari berbagai pengertian membaca di atas, dapat ditarik simpulan bahwa kegiatan membaca adalah suatu kegiatan memahami isi, ide atau gagasan baik yang tersurat maupun tersirat dalam bahan bacaan, sehingga dapat mengambil makna dari pesan yang hendak disampaikan oleh penulis. Dengan demikian, pemahaman menjadi produk yang dapat diukur dalam kegiatan membaca, bukan perilaku fisik pada saat membaca.

\section{Explicit Instruction}

Menurut Kardi (Uno dan Nurdin, 2011:118) Model pembelajaran Explicit Instruction merupakan suatu pembelajaran kooperatif, dimana pembelajarannya dapat berbentuk ceramah, demonstrasi, pelatihan atau praktek dan kerja kelompok.

Menurut archer dan hughes, sebagaimana dikutip oleh Huda (2013:168), Strategi Explicit Instruction adalah salah satu pendekatan mengajar yang dirancang khusus untuk menunjang proses belajar siswa. Strategi ini berkaitan dengan pengetahuan deklaratif dan pengetahuan prosedural yang terstruktur dan dapat diajarkan dengan pola kegiatan yang bertahap, selangkah demi selangkah. Strategi ini sering dikenal dengan model pembelajaran langsung.

Menurut Kardi \& Nur, sebagaimana dikutip oleh Trianto (2009:41-42) ada beberapa ciri-ciri model explicit instruction (pengajaran langsung), yaitu sebagai berikut:

a. Adanya tujuan pebelajaran dan pengaruh model pada siswa termasuk prosedur penilaian belajar.

b. Sintaks atau pola keseluruhan dan alur kegiatan pembelajaran dan

c. Sistem pengelolaan dan lingkungan belajar model yang diperlukan agar kegiatan pembelajaran tertentu dapat berlangsung dengan berhasil. 


\section{METODE PENELITIAN}

Jenis penelitian ini adalah penelitian One-Group Pretest-posttest Design, yaitu melibatkan satu kelompok atau satu kelas. Penelitian ini tidak menggunakan kelas perbandingan namun menggunakan tes awal sehingga besar efek atau pengaruh penggunaan Model Explicit Instruction dapat diketahui secara pasti. Dalam penelitian ini, subjek penelitian terlebih dahulu diberikan tes awal (pretest) untuk mengetahui sejauh mana hasil awal peserta didik sebelum diberikan perlakuan. Desain atau model penelitian yang digunakan dalam penelitian ini adalah desain penelitian yang bersifat eksperimen jenis OneGroup Pretest-Posttest Design.

Dalam penelitian ini yang menjadi populasi adalah seluruh peserta didik dikelas IV SD Inpres Bertingkat Kecamatan Somba Opu Kabupaten Gowa. Dalam penelitian ini yang menjadi sampel adalah seluruh peserta didik dikelas IV A SD Inpres Bertingkat Kecamatan Somba Opu Kabupaten Gowa. Adapun instrumen yang digunakan dalam penelitian ini adalah lembar test. Teknik tes dalam penelitian ini adalah melakukan tes hasil belajar sebanyak dua kali, yaitu sebelum diberikan perlakuan (pre-test) dan setelah diberikan perlakuan (post-test).
Tes ini bertujuan untuk mengetahui pengaruh Model Explicit Instruction terhadap hasil membaca belajar konsep denah (membaca) setelah adanya perlakuan pada kelas eksperimen. Untuk menganalisi data yang diperoleh dari hasil penelitian akan digunakan analisis statistic deskriptif dan inferensial.

HASIL PENELITIAN DAN PEMBAHASAN

Deskripsi hasil belajar Pre-Test Bahasa Indonesia siswa kelas IV SD Inpres Bertingkat Kecamatan Somba Opu Kabupaten Gowa sebelum di terapkan Model Pemebelajaran Explicit Instruction

Berdasarkan tabel skor hasil pretest siswa (Lampiran I) dapat diketahui bahwa pre-test hasil belajar Bahasa Indonesia kelas ekperimen yang memperoleh nilai 30-49 sebanyak 12 orang dan masuk dalam kriteria rendah (Depdikbud), sedangkan siswa yang memperoleh nilai 50-69 sebanyak 6 orang masuk dalam kriteria cukup (Depdikbud), dan siswa yang mendapat kriteria baik atau dengan nilai siswa dari 70-89 sebanyak 5 orang (Depdikbud). 
Dari hasil perhitungan di atas, maka diperoleh nilai rata-rata dari hasil belajar murid kelas IV SD Inpres Bertingkat Kecamatan Somba Opu Kabupaten Gowa sebelum penerapan model Explicit Instruction yaitu 47,65.

Jika hasil tes siswa dikelompokkan ke dalam skala 5 kategori pada pedoman Departemen pendidikan dan kebudayaan (Depdikbud), maka diperoleh distribusi frekuensi dan persentase sebagai berikut :

Berdasarkan tabel 4.2 dan 4.1 menunjukkan bahwa hasil belajar Bahasa Indonesia siswa cukup bervariasi, dan terlihat masih ada siswa yang berada pada kategori rendah yaitu 12 siswa atau 52,17 \% (Depdikbud), kategori sedang yaitu 6 siswa atau 26,08 \% (Depdikbud), dan kategori tinggi yaitu 5 siswa atau 21,73 \% (Depdikbud).

Berdasarkan penjelasan di atas, dapat disimpulkan bahwa hasil belajar siswa kelas IVA SD Inpres Bertingkat kecamatan Somba Opu Kabupaten Gowa setelah diberikan tes hasil belajar (pretest) sebelum diberikannya treatmet dengan menggunakan Model Explicit Instruction berada dalam kategori "rendah", dengan nilai rata-rata 47,65 masuk dalam kriteria rendah (Depdikbud). Skor tertinggi adalah 75 dan skor terendah adalah 30. Dengan kata lain pembelajaran yang diberikan guru masih dalam kategori "rendah" (Depdikbud), ini disebabkan guru lebih banyak menggunakan metode konvensional.

Apabila Tabel 4.3 dikaitkan dengan indikator kriteria ketuntasan hasil belajar murid yang ditentukan oleh peneliti yaitu jika jumlah murid yang mencapai atau melebihi nilai KKM (70) $\geq 70 \%$, sehingga dapat disimpulkan bahwa hasil belajar Bahasa Indonesia murid Kelas IV SD Inpres Bertingkat Kecamatan Somba Opu Kabupaten Gowa pada materi konsep denah belum memenuhi kriteria ketuntasan hasil belajar secara klasikal dimana murid yang tuntas hanya $21,73 \% \leq 70 \%$.

\section{Deskripsi hasil belajar Post-test Bahasa Indoneisa siswa kelas IV SD Inpres Bertingkat Kecamatan Somba Opu Kabupaten Gowa}

Selama penelitian berlangsung terjadi perubahan terhadap hasil siswa setelah diberikan perlakuan (Treatment). Perubahan tersebut berupa hasil belajar yang datanya diperoleh setelah diberikan post-test, perubahan tersebut dapat dilihat dari data berikut ini: 


\begin{tabular}{|l|l|l|c|}
\hline No & Skor & Kategori & Frekuensi \\
\hline 1 & $0-29$ & $\begin{array}{l}\text { Sangat } \\
\text { Rendah }\end{array}$ & - \\
\hline 2 & $30-49$ & Rendah & 1 \\
\hline 3 & $50-69$ & Sedang & 5 \\
\hline 4 & $70-89$ & Tinggi & 17 \\
\hline 5 & $90-$ & $\begin{array}{l}\text { Sangat } \\
\text { Tinggi }\end{array}$ & - \\
\hline \multicolumn{2}{|c|}{ Jumlah } & & 23 \\
\hline
\end{tabular}

Berdasarkan tabel hasil skor hasil belajar Posttest siswa (Lampiran 2) dapat diketahui bahwa post-test hasil belajar Bahasa Indonesia kelas ekperimen yang memperoleh nilai 30 49 sebanyak 1 orang dan mengalami peningkatan setelah diberikan perlakuan. Sedangkan siswa yang memperoleh nilai 50-69 sebanyak 5 orang masuk dalam kriteria cukup (Depdikbud) dan ini mengalami peningkatan yang cukup, dan siswa yang mendapat kriteria baik atau dengan nilai siswa dari 70-89 sebanyak 17 orang (Depdikbud).

Untuk mencari mean (rata-rata) nilai post-test dari murid kelas IV SD Inpres Bertingkat Kecamatan Somba Opu Kabupaten Gowa dapat dilihat melalui tabel (lampiran).

Dari data tabel perhitungan untuk mencari mean ( rata - rata ) nilai posttest (lampiran) dapat diketahui bahwa nilai dari $\sum f x=1598$, sedangkan nilai dari N sendiri adalah 23.

Dari hasil perhitungan di atas, maka diperoleh nilai rata-rata dari hasil belajar murid kelas IV SD Inpres Bertingkat Kecamatan Somba Opu Kabupaten Gowa setelah penerapan model Explicit Instruction yaitu 69,47.

Deskripsi Aktivitas Belajar Bahasa Indoensia Siswa Kelas IV SD Inpres Bertingkat Kecamatan Somba Opu Kabupaten Gowa Selama Diterapkan Pembelajaran dengan Menggunakan Model Explicit Instruction

Adapun deskripsi dari hasil pengamatan aktivitas siswa dalam mengikuti pembelajaran yaitu hasil pengamatan pertemuan I dan II menunjukkan bahwa, Presentase kehadiran siswa sebesar 97,82\% yang merupakan kategori aktif, selanjunya persentase murid yang tidak memperhatikan pada saat guru menjelaskan materi sebanyak 54,34\% dikatakan kategori tidak aktif, Persentase murid yang memperhatikan pada saat guru menjelaskan materi $73,91 \%$, persentase murid yang menjawab pertanyaan guru baik secara lisan maupun tulisan 80,43\%, Persentase murid yang bertanya pada 
saat proses pembelajaran berlangsung 54,34\%, Persentase murid yang mengajukan diri untuk mengerjakan soal di papan tulis 73,91\%, Persentase murid yang mengerjakan soal dengan benar $80,43 \%$, Persentase murid yang mampu menyimpulkan materi pembelajaran pada akhir pembelajaran 73,91\%, jika di rata-ratakan persentase aktivitas murid terhadap pelaksanaan Bahasa Indonesia dengan menggunakan model pembelajaran Explicit Instruction dengan materi Konsep Denah yaitu sebesar 73,63\%.

Sesuai dengan kriteria aktivitas siswa yang telah ditentukan peneliti yaitu siswa dikatakan aktif dalam proses pembelajaran jika jumlah siswa yang aktif $\geq 70 \%$ baik aktivitas siswa perindikator maupun rata-rata aktivitas siswa, dari hasil pengamatan rata-rata presentase siswa yang aktif melakukan aktivitas yang diharapkan yaitu mencapai $73,63 \%$, sehingga dapat disimpulkan aktivitas siswa dalam proses pembelajaran Bahasa Indonesia dengan materi Konsep Denah telah mencapai kriteria aktif.

Pengaruh penerapan Model Explicit Instruction terhadap hasil belajar siswa pada Mata Pelajaran Bahasa Indoensia Kelas IV SD Inpres

\section{Bertingkat Kecamatan Somba Opu Kabupaten Gowa}

Sesuai dengan hipotesis penelitian yaitu "penggunaan Model Explicit Instruction memiliki pengaruh terhadap hasil belajar konsep denah Mata Pelajaran Bahasa Indoensia Kelas IV SD Inpres Bertingkat Kecamatan Somba Opu Kabupaten Gowa". Maka teknik yang digunakan untuk menguji hipotesis tersebut adalah statistik diferensial melalui perhitungan dengan menggunakan uji-t.

Analisis skor pre-test dan posttest siswa dapat dilihat pada tabel 4.8 (Lampiran 3). Adapun Langkah-langkah dalam pengujian hipotesis adalah sebagai berikut:

1. Mencari harga $\mathrm{Md}$ dengan menggunakan rumus:

$$
\text { Md }=\frac{\sum d}{N}
$$

2. Mencari harga " $\sum \mathrm{x}^{2} \mathrm{~d}$ " dengan menggunakan rumus:

$$
\sum \mathrm{x}^{2} \mathrm{~d}=\sum \mathrm{d}^{2}-\frac{(\Sigma d)^{2}}{N}
$$

Menentukan harga tHitung

$$
\mathrm{T}=\frac{M d}{\sqrt{\frac{\Sigma \chi^{2} \mathrm{~d}}{N(N-1)}}}
$$

3. Menentukan harga t Tabel

Untuk mencari tTabel peneliti menggunakan tabel distribusi $\mathrm{t}$ dengan taraf signifikan $\alpha=0,05$ dan 
$\mathrm{d} . \mathrm{k}=\mathrm{N}-1=23-1=22$ maka diperoleh t0,05=1,71 (Lampiran).

Setelah diperoleh tHitung= 7,456 dan $\mathrm{t}$ tabel $=1,71$. Maka diperoleh tHitung $>t$ tabel atau 7,456 $>1,71$, sehingga dapat disimpulkan bahwa Ho ditolak dan Ha diterima. Ini berarti bahwa ada Pengaruh Penggunaan Model Explicit Instruction Terhadap Hasil Belajar Bahasa Indonesia konsep denah pada Siswa Kelas IV SD Inpres Bertingkat Kecamatan Somba Opu Kabupaten Gowa.

Model Explicit Instruction dalam pembelajaran dapat menjadi cara yang efektif untuk mengajarkan informasi dan pengetahuan faktual yang sangat terstruktur. Menurut Rosenshine \& Steven (1986:3) Explicit Instruction merupakan pembelajaran langsung yang khusus dirancang untuk mengembangkan belajar siswa tentang pengetahuan prosedur dan pengetahuan deklaratif yang dapat diajarkan dengan pola selangkah demi selangkah.

Selanjutnya nilai rata-rata hasil post-test adalah 69,47. Jadi hasil belajar Bahasa Indonesia dalam hal keterampilan berbicara setelah diterapkan model pembelajaran Explicit Instruction mempunyai hasil belajar yang lebih baik dibanding dengan sebelum penerapan model pembelajaran Explicit Instruction. Selain itu persentasi kategori hasil belajar Bahasa Indonesia murid juga meningkat yakni rendah sebanyak 4,34\%, sedang $21,73 \%$, tinggi $73,91 \%$.

Berdasarkan hasil observasi terdapat perubahan pada siswa dimana pada awal kegiatan ada beberapa siswa yang melakukan kegiatan lain dan bersifat acuh selama pembelajaran berlangsung. Hal ini dapat dilihat pada pertemuan pertama siswa yang tidak memperhatikan sebanyak sebanyak 15 orang. Sedangkan pada pertemuan kedua hanya 10 orang siswa yang melakukan kegiatan lain dan tidak memperhatikan pada saat pembelajaran berlangsung. Pada awal pertemuan hanya sedikit siswa yang aktif pada saat pembelajaran berlangsung, tapi sejalan dengan pembelajaran menggunakan Model Explicit Instuction siswa maulai aktif pada setiap pertemuan.

Berdasarkan

observasi banyaknya siswa yang mulai aktif menanggapi dan menjawab berbagai pertanyaan yang dilontarkan guru serta mampu menjawab pertanyaan dari siswa lain sehingga siswa lain ikut termotivasi untuk mengikuti pembelajaran. Proses pembelajaran yang menyenangkan membuat siswa 
tidak lagi keluar masuk pada saat pembelajaran berlangsung.

\section{KESIMPULAN DAN SARAN}

Berdasarkan pengujian hipotesis dan pembahasan hasil penelitian pada bab sebelumnya, maka dapat ditarik kesimpulan bahwa penggunaan Model Explicit Instruction dalam pembelajaran Bahasa Indonesia dengan materi Konsep denah berpengaruh terhadap hasil belajar siswa kelas IV SD Inpres Bertingkat Kecamatan Somba Opu Kabupaten Gowa. Keadaan ini dapat dilihat dari hasil tes yang menunjukkan bahwa posttest yang diberi perlakuan melalui Model Explicit Instruction mendapatkan nilai rata-rata lebih tinggi yaitu 69,47 dibandingkan dengan pretest yang tidak menerima perlakuan pembelajaran media yaitu 59,80. Berdasarkan uji t baik taraf signifikan diperoleh $t_{\text {hitung, }} 7,45$ dan $t_{\text {tabel }}=1,71$. Karena $t_{\text {hitung }}>t_{\text {tabel }}$ maka ada pengaruh terhadap hasil belajar yang diberi perlakuan dengan Menggunakan model Explicit Instruction. Maka berdasarkan pengujian tersebut penggunaan Model Explicit Instruction berpengaruh jika diterapkan pada proses pembelajaran Bahasa Indoensia dengan materi konsep denah pada murid kelas IV SD Inpres Bertingkat Kecamatan Somba Opu
Kabupaten Gowa. Berdasarkan temuan yang berkaitan dengan Pengaruh Penggunaan Model Explicit Instruction Terhadap Hasil Belajar Siswa Pada Mata Pelajaran Bahasa Indonesia Konsep Denah Murid Kelas IV SD Inpres Bertingkat Kecamatan Somba Opu Kabupaten Gowa maka dikemukakan beberapa saran Kepada para pendidik khsususnya guru yang berada di SD Inpres Bertingkat Kecamatan Somba Opu Kabupaten Gowa disarankan menggunakan Model pembelajaran Explicit Instruction untuk meningkatkan keaktifan serta semangat siswa dalam belajar.

Kepada Peneliti, diharapkan mampu mengembangkan model pembelajaran Explicit Instruction ini dengan menerapkan pada materi lain untuk mengetahui apakah pada materi lain cocok dengan model pembelajaran ini demi tercapainya tujuan yang diharapakan. Kepada peneliti lain, diharapkan agar dapat mengembangkan dan memperkuat model ini serta memperkuat hasil penelitian ini dengan cara mengkaji terlebih dahulu sehingga mampu mengadakan penelitian yang lebih sukses. 


\section{DAFTAR PUSTAKA}

Ahmad. 2016. Teori Belajar \& Pembelajaran di Sekolah Dasar. Jakarta: Kencana.

Arikunto, Suharsini. 2007. Prosedur Penelitian Suatu Pendekatan Prakter. Jakarta: Rineka Cipta.

Armayani. 2015. Pengaruh Media Blok Dienes Pada Penjumlahan Mata Pelajaran Matematika Dalam Meningkatkan Motivasi Belajar Siswa Kelas I Sd Negeri 321Ara Kecamatan Bontobahari Kabupaten Bulukumba

Emzir. 2014. Metodologi Penelitian Pendidikan. Jakarta: PT.Rajagrafindo Persad

Kurt, S. 1987. Membina Hasrat Belajar di Sekoluh. Bandung: Remaja Karya CV Bandung.

Pande, W. A. 2014. Penerapan Model Pembelajaran Explicit Instruction Berbantuan Media Kongkrit Untuk Meningkatkan Hasil Belajar IPA Siswa Kelas VI SDN 17 Dangin Puri Kota Denpasar, (Online), Vol 2, No. 1

(http://ejournal.undiksha.ac.id/in dex.php/JJPGSD/article/view/37 44, diakses 10 Februari 2017).

Rahayu. 2016. Pengaruh Pembelajaran Kooperatif Tipe STAD (Student Team Achievement Division) Terhadap Hasil Belajar Pendidikan Kewarganegaraan (PKn) Siswa SDN 199 Arasoe Kecamatan Cina Kabupaten Bone

Rahmah. 2015. Pengaruh Penerapan Metode Pembelajaran Brainstorming terhadap Peningkatan Hasil Belajar Siswa
Pada Mata Pelajaran Bahasa Indonesia Kelas $V$ SD Swasta Semen Tonasa II Kabupaten Pangkep. Skripsi Tidak diterbitkan. Makassar: Unismuh Makassar.

Rusman. 2010. Model-Model Pembealajaran; Mengembangkan Profesionalisme Guru. Jakarta: Rajawali Pers.

Sahabuddin. 2007. Mengajar dan Belajar. Makassar: Universitas Negeri Makassar.

Sri, N. P. 2015. Penerapan Model Pembelajaran Explicit Instruction Pada Mata Pelajaran IPA di Kelas IV SD 01 Suwawa Kecamatan Suwawa Kabupaten Bone Bolango, (Online), Jilid 1, No. 1 (http://eprints.ung.ac.id/10041/, diakses 10 Februari 2017).

Suhaeda. 2015. Pengaruh Penerapan Model Pembealajaran Kuantum Learning terhadap Hasil Belajar Membaca Siswa dalam Mata Pelajaran Bahasa Indonesia Kelas IV SD Inpres Paccinongang Kecamatan Somba Opu Kabupaten Gowa. Skripsi tidak diterbitkan. Makassar: Unismuh Makassar.

Sudijono. 2014. Pengantar Statistik Pendidikan. Jakarta: PT Rajsgrafindo Persada

Sugiyono. 2015. Metode Penelitian Kualitatif dan Kuantitatif dan $R \& D$. Bandung: Alfabeta.

Sugiyono. 2014. Metode Penelitian Kualitatif dan Kuantitatif dan $R \& D$. Bandung: Alfabeta.

Sugiyono. 2007. Desain Penelitian. Bandung: Alfabeta. 
Tim Kreasi Bahasa. 2005. Kamus Bahasa Indonesia: Kreasi Media.

Trianto. 2011. Model Pembelajaran Explicit Instruction. Jakarta: PT. Bumi Aksara.

Trianto. 2009. Mendesain Model Pembelajaran Inovatif-Progresif: Konsep, Landasan, dan Implementasinya Pada Kurikulum Tingkat Satuan Pendidikan
(KTSP). Jakarta: Kencana Prenata Media Group.

Undang-Undang Republik Indonesia Nomor 20 Tahun 2003 tentang Sistem Pendidikan Nasional. 2014. Jakarta: Sinar Grafika.

Winkel. W S. 1996. Psikologi Pengajaran. Jakarta: Tarsito.

Zainal, A. 2014. Model-Model, Media, dan Strategi Pembelajaran Kontekstual (Inovatif). Bandung: Yrama Widya. 